\title{
Bridge construction cost saving from using LRB (Lead Rubber Bearing) in the area prone to earthquake, Kenteng bridge case study
}

\author{
Ariono Dhanis ${ }^{1, *}$, Herdianto Arifin ${ }^{2}$, and Iwan Zarkasi ${ }^{3}$ \\ ${ }^{1}$ Young Functional Official of Ministry of Public Works and Housing, Highway General Directorate, Bridge Directorate, Jl. Pattimura \\ No 20 Lt 6, South Jakarta, Indonesia \\ ${ }^{2}$ Middle Functional Official of Ministry of Public Works and Housing, Highway General Directorate, Bridge Directorate, Jl. Pattimura \\ No 20 Lt 6, South Jakarta, Indonesia \\ ${ }^{3}$ Head of Bridge Directorate of Ministry of Public Works and Housing, Highway General Directorate, Bridge Directorate, Jl. Pattimura \\ No 20 Lt 6, South Jakarta, Indonesia
}

\begin{abstract}
There are many ways to reduce the earthquake force excited in the bridge structure, such as the use of Lead Rubber Bearing, Sliding Isolation Pendulum, and Damper/Lock Up Device. The concern that described in this paper is Lead Rubber Bearing support to damp earthquake thrust above the pier. The declared by the manufacturer guarantee is that the LRB can weaken the shock for about $30 \%$. The analysis executed here is a response spectrum analysis calculating the natural frequency of the bridge. The contractual cost of the structure (with LRB structure) with the non-LRB structure were compared. We did not compare in terms of reinforced concrete volume reduction because the price of the LRB each and the price of the concrete with rebar per $\mathrm{m} 3$ are different. From the analysis, it is shown that without LRB, the price of the bridge will be increased at 19\% from the original contractual price (before tax) or 16\% saving. From this point, it is important to use LRB in our earthquake-prone area as the conclusion.
\end{abstract}

\section{Introduction}

In order to cut down the earthquake tremor, there are some devices installed as options instead of ductility requirement, which is quite famous in Indonesia, these are Lead Rubber Bearing, Sliding Isolation Pendulum, and Damper.

Sliding Isolation Pendulum Bearing (SIPB) is as follows [7]:

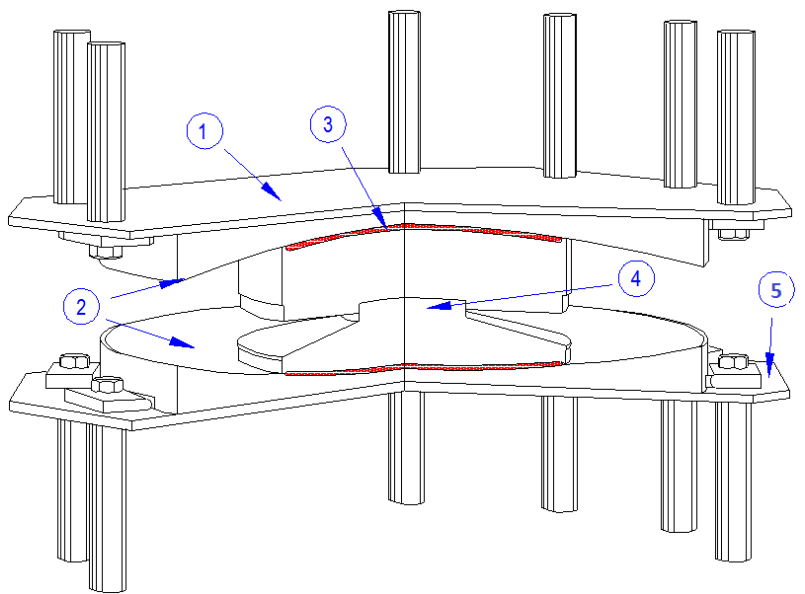

Fig. 1. SIPB (Sliding Isolation Pendulu $m$ Bearing) With the definition per each part:

1 is Top Achor Plate

2 is Main Sliding Surface
3 is Sliding Material

4 is Rotation Element

5 is Bottom Achor Plate

SIPB is used in Holtekam Bridge, in Papua. Damper Earthquake reduction method (Lock Up Device) uses the viscous liquid to dissipate the tremor energy. This system is used in Pasopati Bridge [6], Bandung, Western Java.
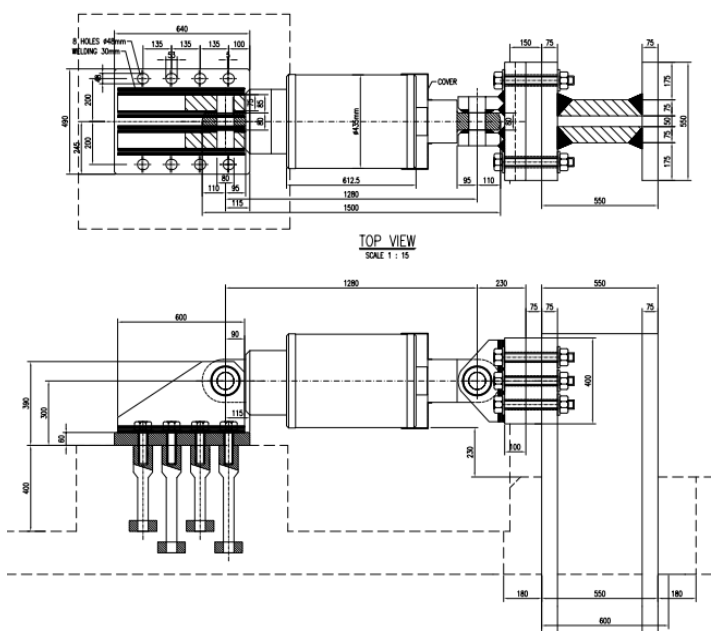

Fig. 2. Lock Up Device

Indonesia is a country prone to earthquakes, which is surrounded by fault and ring of fire except Kalimantan

\footnotetext{
*Corresponding author: ariono.dhanis@gmail.com
} 
Island. Indonesia Earthquake happening is shown in the following figure.

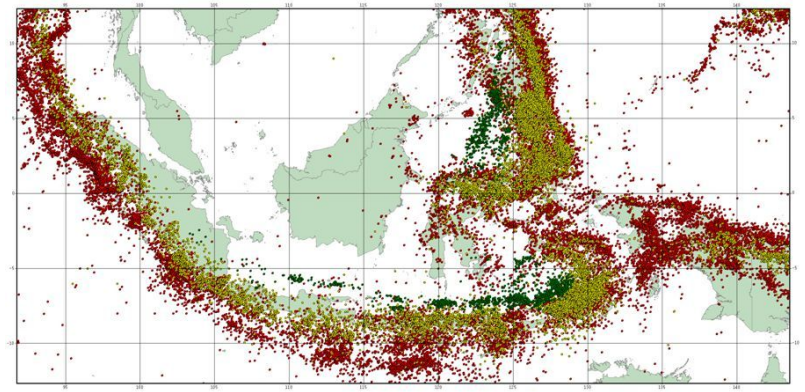

Fig. 3. Records of Earthquake in Indonesia

The red dot color is shallow earthquake $(<70 \mathrm{~km})$, yellow dot color is intermediate earthquake $(70-300 \mathrm{~km})$, green dot color is deep earthquake $(>300 \mathrm{~km})$, Iswandi Imran, E.K. Kertapati, 2018 [4].

The earthquake in Indonesia has been regulated in SNI 2833:2016 with a map in the year 2017.

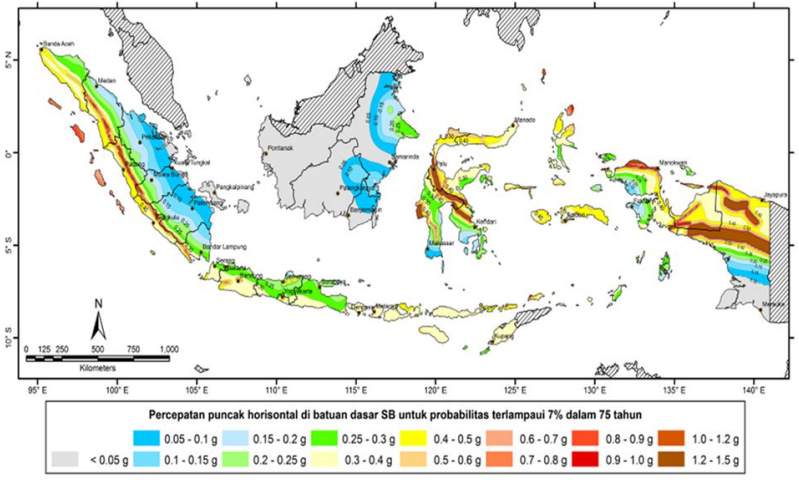

Fig. 4. Bed Rock Tremor Acceleration with probability exceeding $7 \%$ within 75 years

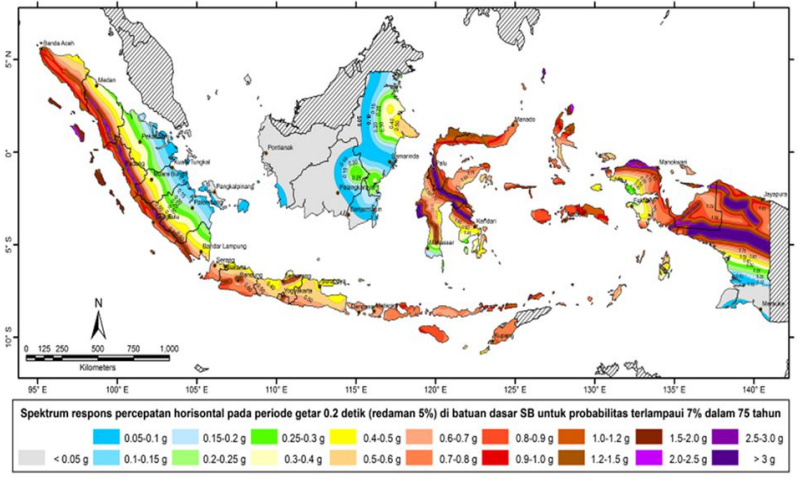

Fig. 5. Bed Rock Tremor Acceleration with probability exceeding $7 \%$ within 75 years on the 0,2 second period of vibration (damping 5\%)

In Indonesia, the bridge is divided into [2]:

1. Critical Bridge

2. Essential Bridge

3. Other Bridge
The foundation of the bridge must be stronger than the pier, so the magnitude was divided into the earthquake with 1,5 typically. For the detail analysis reader can refer to push over design.

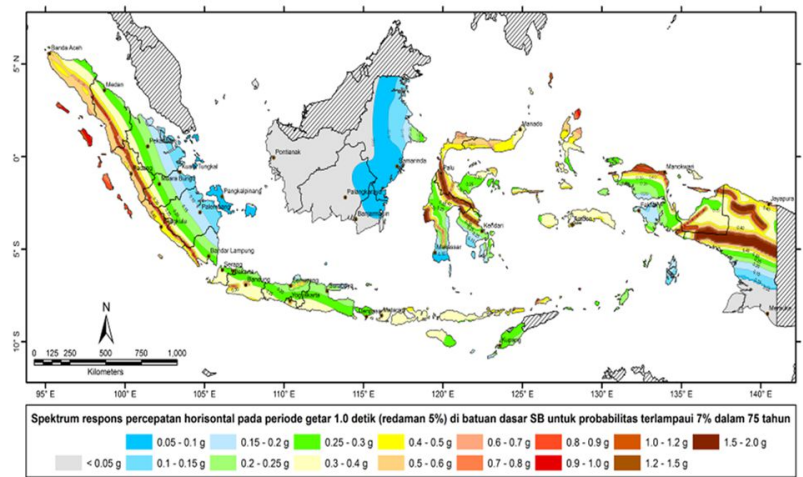

Fig. 6. Bed Rock Tremor Acceleration with probability exceeding $7 \%$ within 75 years on the 1 second period of vibration (damping $5 \%$ )

$$
\begin{gathered}
\text { Upper Structure Earthquake Force Design } \\
=\frac{\text { Earthquake Force Design }}{1,5}
\end{gathered}
$$

\section{Foundation Structure Earthquake Force Design}

$$
=1 x \text { Earthquake Force Design }
$$

Foundation Earthquake design takes into account all the earthquake magnitude without reduction to avoid plastic hinge formed in a pile.

\section{Method}

To mitigate the earthquake that we discussed here, we use LRB (Lead Rubber Bearing), with the properties of the material as follows.

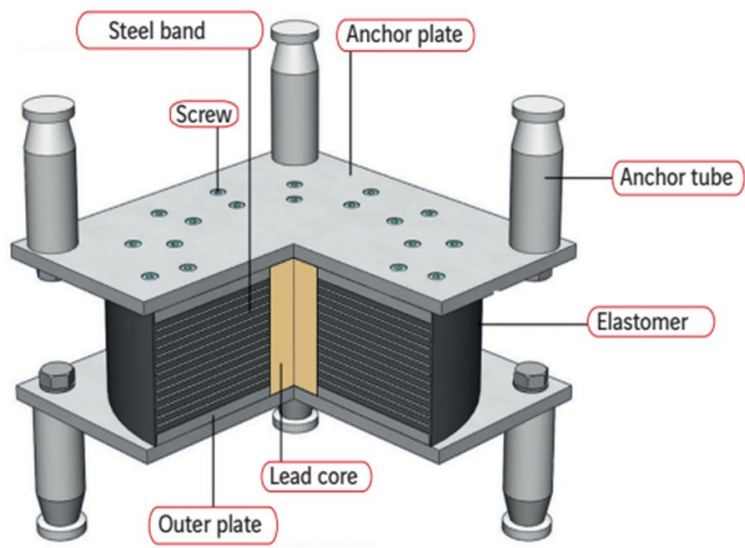

Fig. 7. Lead Rubber Bearing Section View

The lead core is a smart material that can return to its original form once it is deformed (by the earthquake). 
First, the structural model was created. The column is modeled as follows:

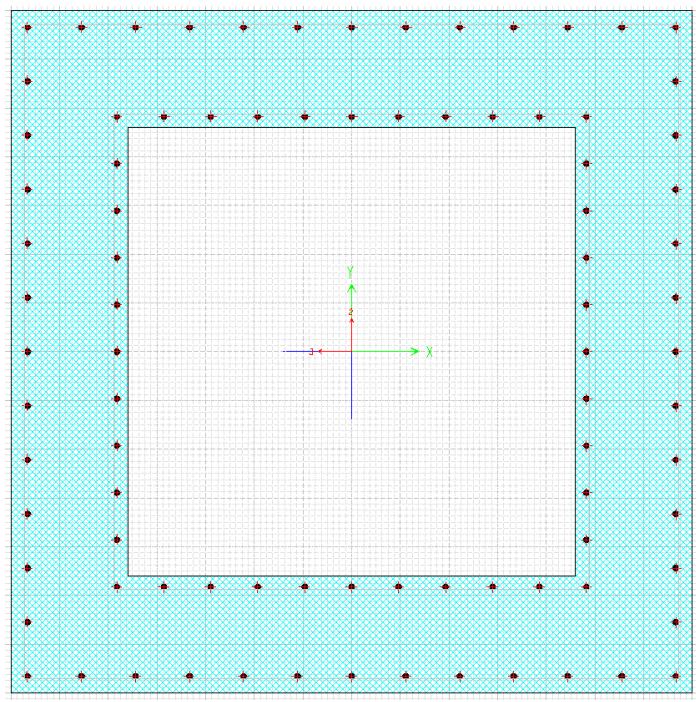

Fig. 8. The Cross-Section of the Pier (The Biggest Pier)

The inner part is an Opening. And we define the structure as follows, extruded view.

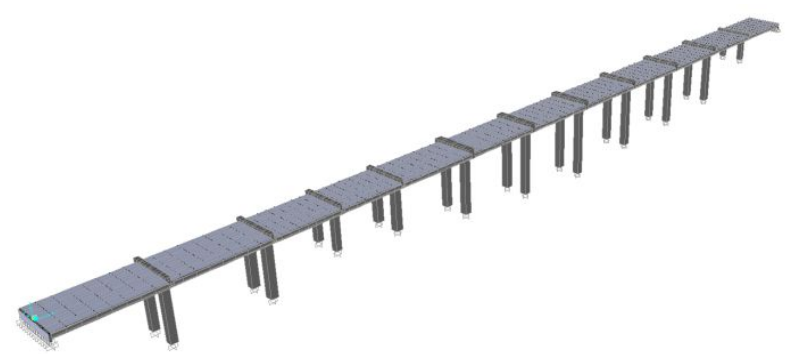

Fig. 9. The Structural Modelling of The Bridge (Kenteng Bridge)

The span between each pier is 30 meter-40 meters. The dimension of the column is $3000 \times 3000$ (with 400 $\mathrm{mm}$ thickness), 3500x3500 (with $500 \mathrm{~mm}$ thickness), and $3500 \times 3500$ (with $600 \mathrm{~mm}$ thickness). The slab thickness is $220 \mathrm{~mm}$. The design use PCI girder (I girder).

\section{Analysis}

After the calculation of the response spectrum, we come up with (for medium soil):

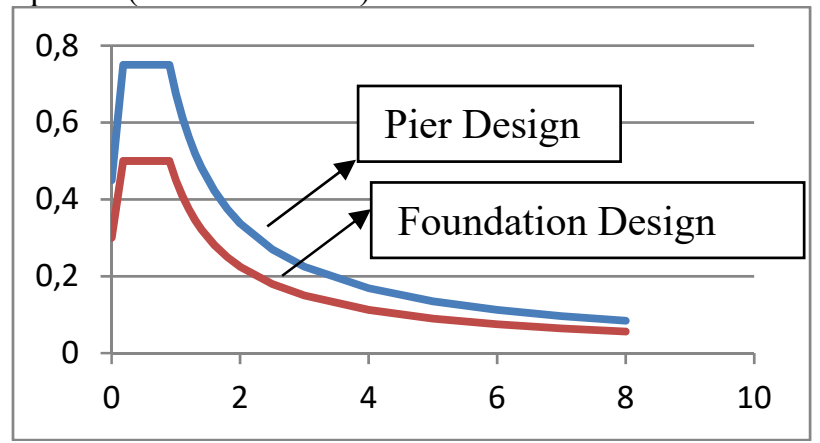

Fig. 10. Response Spectrum Chart Period (second) x Axis vs Tremor Acceleration (g) y Axis
For the live load, we simplify only take into account the $9 \mathrm{kPa}(0,9$ ton $/ \mathrm{m} 2)$ [1] multiply by the earthquake live load reduction factor 0,3 for essential bridge. For simplicity, we only take into account the lateral earthquake force (1 direction).

By design, the capacity of the biggest columns is:

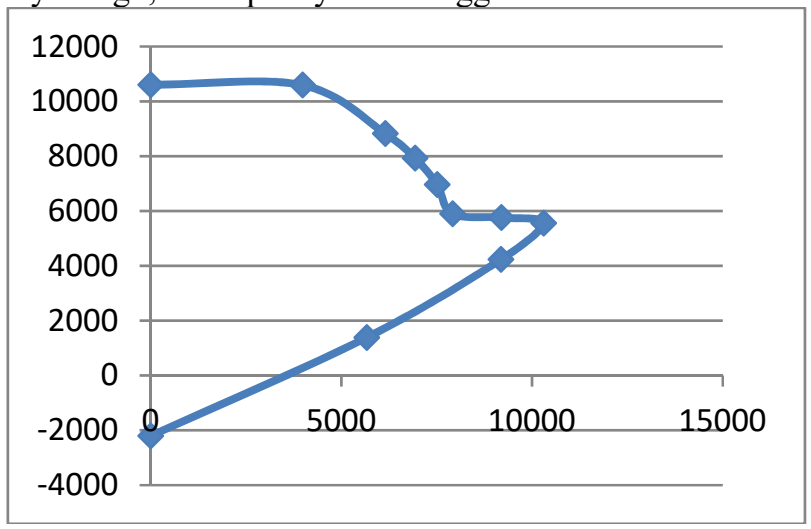

Fig. 11. Column Interaction Diagram of Axial Force (y-axis: ton) vs. Momen (x-axis: ton-m)

The biggest moment that can be resisted by the column is 10.000 ton-m. However, the actual happen column moment that due to the earthquake is 15.000 ton$\mathrm{m}$ as follows.

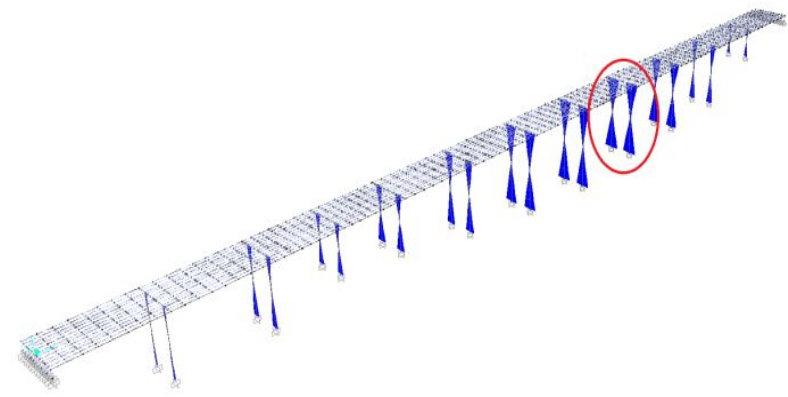

Fig. 12. Response Spectrum Moment that is used for the design criteria for non-LRB structure analysis.

First, we add the column in the middle of the pier head as follows.

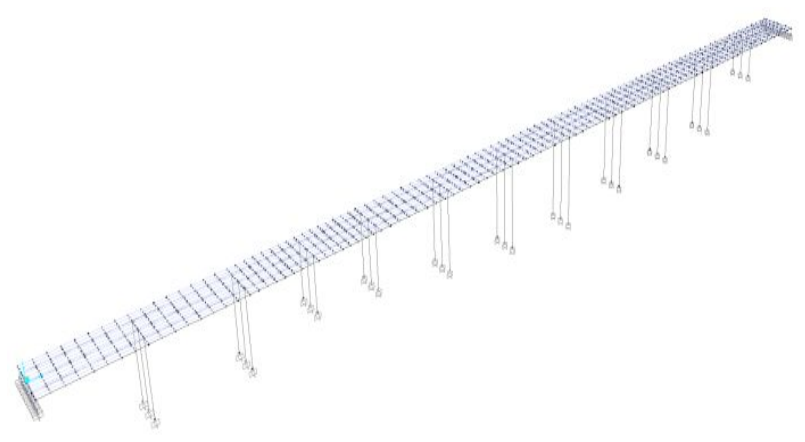

Fig. 13. Trial by Adding 1 Column in the Middle

The three-column configuration result in 13.000 ton-m moment due to earthquake shock. Since 13.000 ton- $\mathrm{m}$ is still higher than 10.000 ton-m, the column capacity, we add more one column in the trial as follows. 


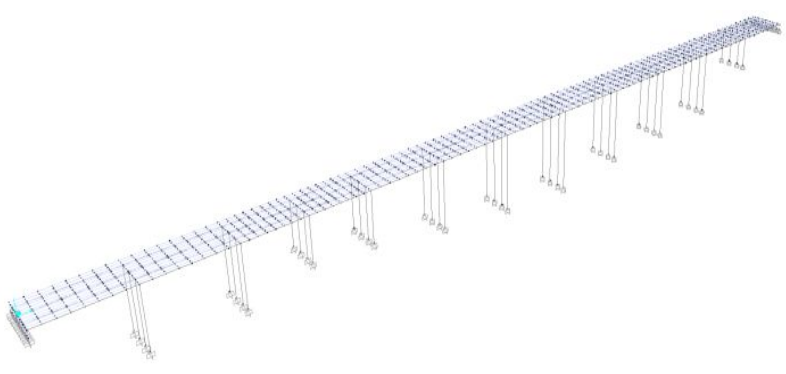

Fig. 14. Trial by Adding 2 Column in (1 in the middle, one on the side)

After we add one more column, the moment happens in the analysis due to the earthquake reduced to 10.000 ton-m, which is equal to the column capacity. By combining two piers, the moment that happens is only somehow 10.000 ton-m. So it is clear that without LRB, the volume of concrete to create pier will be multiplied by two times. From this moment, we can also conclude that the volume of footing/pile cap will be multiplied by two times, and so does the pile. This conclusion leads to the use of LRB is the right decision. The trial chart is as follows.

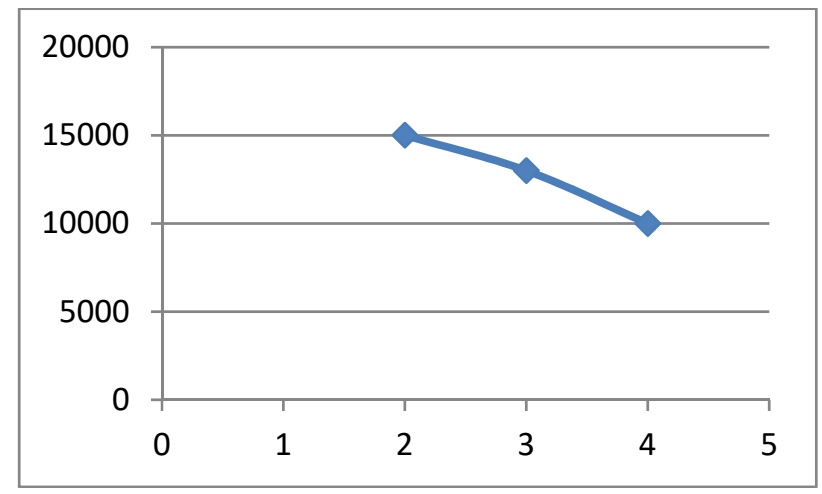

Fig. 15. The trial chart to get 10.000 ton-m moment (X-Axis: The Number of Column/Pier; Y-Axis: The Moment Due to Earthquake ton-m)

To compare whether using LRB [3] will be more economical, we use the price data of LRB. LRB price (including installation and procurement): 94 million rupiah. There are 360 LRB installed on-site, in Kendeng Bridge. So the cost of the LRB will be 33,840 million rupiah (360* 94 million rupiah). The contract price is 424,000 million rupiah. So. The deducted price without LRB will be 390,160 million rupiahs. This number (390,160 million rupiah) is the price without the earthquake-resistant system. By multiplying the number of the pier, footing, and foundation with 2 resulted in the additional number of price 111,081 million rupiah, it was 19 percent more than 424,000 million rupiah [5]. The more detailed calculation of the additional amount is as follows.

1. Pier $=2563 \mathrm{~m} 3 * 1,986,000$ rupiah $=5,090,118,000$ rupiah
2. Footing $=20,394 \mathrm{~m} 3 * 1,896,000$ rupiah $=$ $38,667,024,000$ rupiah

3. Soil Bored Pile Diameter 1,5 meter $=3,370 \mathrm{~m} 1 *$ $7,500,000$ rupiah $=25,275,000,000$ rupiah

4. Stone Bored Pile Diameter 1,5 meter $=2,564 \mathrm{ml} *$ $16,400,000$ rupiah $=42,049,600,000$ rupiah

5. Elastomeric Bearing $\mathrm{Pad}=360$ each $* 4,000,000$ rupiah $=1,440,000,000$ rupiah

Total Additional Cost $=5,090,118,000+38,667,024,000$

$+25,275,000,000+42,049,600,000+1,440,000,000=$ $112,521,742,000$ rupiah

The total cost of the construction without LRB will be: $112,521,742,000+424,000,000,000=502,681,742,000$ rupiah

$$
\begin{gathered}
\text { Saving }=\frac{\text { Price without } L R B-\text { Price with } L R B}{\text { Price without } L R B} * 100 \% \\
\text { Saving }=\frac{502,681,742,000-424,000,000,000}{502,681,742,000} * 100 \% \\
\text { Saving }=16 \%
\end{gathered}
$$

\section{Conclusion}

The price increase without using LRB will be $16 \%$ of the budget. It can be concluded that by using LRB the saving of the budget for this type of bridge is $16 \%$. It is important to use LRB in nowadays bridge as it will reduce the earthquake force a lot. This study is only limited to the simple span structure and continuous beams, further study need to be developed into more detail study of the behaviour of the LRB during and after the earthquake for more sophisticated bridge such as cable stayed or balance cantilever bridge.

\section{Reference}

1. Anonim, Pembebanan Untuk Jembatan (Indonesia Bridge Loading Code: National Standard) SNI 1725:2016. (2016)

2. Anonim, Perencanaan Jembatan terhadap Beban Gempa (Earthquake Bridge Loading: National Standard) SNI 2833:2016. (2016)

3. Hermani, Wahyuningsih Tri, J. Infrastruktur 5 (01) (2019)

4. Imran, Iswandi, Konsep Perancangan Struktur Jembatan di Wilayah Rawan Gempa (Structural Design in Earthquake Prone Area), Naskah Kuliah (2018)

5. PT. Trans Marga Jateng, Kenteng Bridge Bill of Quantity. (2018)

6. PUSJATAN, Pasopati Bridge Inspection Plan. (2016)

7. Suryadi, Tri, Sliding Isolation Pendulum Bearing for Holtekam Bridge as Earthquake Mitigation Solution, HPJI Paper. (2016) 